\title{
Danica Čerče
}

University of Ljubljana

Faculty of Economics, Slovenia

\section{Shaping Images of Australia through Translation: Doris Pilkington and Sally Morgan in Slovene Translation}

\author{
Summary
}

By examining the Slovene translations of the novels My Place and Follow the Rabbit-Proof Fence by the Australian indigenous authors Sally Morgan and Doris Pilkington, this article seeks to highlight how they contribute to the bridging of the gap between the two cultures. In particular, and in accord with Gideon Toury's 1995 proposal to analyse a translation in terms of its "'adequacy' in relation to the source text, and its 'acceptability' to the target audience," it aims to establish whether the translators achieved a balance between domestication and foreignisation translation strategies, and how they transposed particular narrative styles and cultural signifiers of Aboriginal writing from the source to the target texts (Limon 2003, 640).

Key words: Australian indigenous literature, Sally Morgan, Doris Pilkington, My Place, Follow the Rabbit-Proof Fence, source texts, Slovene translation, appropriateness of translation

\section{Oblikovanje podob o Avstraliji v prevodnih besedilih: Doris Pilkington in Sally Moran v slovenskem prevodu}

\author{
Povzetek
}

Pričujoča razprava se ukvarja $\mathrm{z}$ analizo slovenskih prevodov romanov My Place in Follow the RabbitProof Fence avstralskih staroselskih pisateljic Sally Morgan in Doris Pilkington in poskuša ugotoviti, $\mathrm{v}$ kolikšni meri prevoda prispevata k zbližanju obeh kultur. Opirajoč se na kritiško mnenje Gideona Touryja, da je prevode potrebno ocenjevati z gledišča njihove "ustreznosti originalu in sprejemljivosti za ciljno publiko," avtorica raziskuje, kako je prevajalkama omenjenih del uspelo ustvariti pravilno razmerje med udomačitveno in potujitveno prevajalsko strategijo, in kako sta $\mathrm{v}$ ciljno besedilo prenesli posamezne pripovedne načine in kulturne posebnosti aboriginskega pisanja (Limon 2003, 640).

Ključne besede: avstralska staroselska književnost, Sally Morgan, Doris Pilkington, My Place, Follow the Rabbit-Proof Fence, izhodiščno besedilo, slovenski prevod, ustreznost prevoda 


\section{Shaping Images of Australia through Translation: Doris Pilkington and Sally Morgan in Slovene Translation}

\section{Introduction}

Since the late 1970's, Australia has witnessed an upsurge in all fields of indigenous creative expression. Consequently, and as statistical evaluations of bibliographies have shown, the worldwide appeal and the number of translations of Australian indigenous literature have also increased significantly. The most prolific and the largest market for this literature in translation has been continental Europe, with roughly ninety translations published so far (Haag 2009). The first translated Aboriginal book on the European market was the Polish edition of Kath Walker's Stradbroke Dreamtime in 1977. Around the same time (in 1978), Mladinska knjiga published $V$ sanjskem času: bajanja in verovanja avstralskih rjavih ljudstev, a book of stories based on Aboriginal oral tradition collected and translated by Dušan Ogrizek. It was not until 2003 that, by means of a series of cultural events organised in Ljubljana and dubbed 'Australian Spring,' Slovene readers became acquainted with contemporary Aboriginal literature. The festival saw the publication of two collections: Vesolje okrog kuščarja (translated and collected by Bert Pribac and David Brooks), an overview of contemporary Australian poetry that includes works by two indigenous authors, Oodgeroo Nunuccal and Lionel G. Fogarty, and Konec sanjske dobe (translated and collected by Bert Pribac), a small anthology of verse by indigenous authors Oodgeroo Noonuccal, Jack Davis, Kevin Gilbert, Lionel G. Fogarty, Herb Wharton, Mudrooroo Narrogin, Bobbi Sykes, Lisa Bellear, and some others.

In the ensuing years, indigenous peoples' issues have received increasing media attention, and other books have found their way to the desks of Slovene translators and publishers. First came the anthology of short narrative prose Kenguru na plaži (translated by Katarina Mahnič and published by Založba Miš in 2007). ${ }^{1}$ This was followed by Sally Morgan's autobiography My Place, translated by Tamara Bosnič under the title V objem korenin (Založba Miš, 2007), and Doris Pilkington's Follow the Rabbit-Proof Fence, published as Zajčja ograja in Andreja Blažic-Klemenc's Slovene version (Založba Eno, 2008). In the same year, and only one year after its first publication in Sweden, Sanje published the Slovene translation of Terra nullius: A Journey through no one's land, by literary historian Sven Linquist. ${ }^{2}$ Most recently, Založba Miš published Love Like Water (Ljubezen kot voda, 2009), a novel on Aboriginal themes by the Australian writer Meme McDonald. These successive publications are evidence of an important opening of Slovene cultural space to works by indigenous Australian authors or other authors dealing with multicultural coexistence in Australia.

An issue worth considering is the adaptation of these works in Slovene culture. By 'adaptation' I mean, following Aldo Di Luzio, Susanne Guenthner and Franca Orletti, the "translation of culture which aims at making the experience of other peoples understandable" to target readers (Mazi-Leskovar 2009, 58). Particularly in cases when readers are exposed to a remote culture and Aboriginal cultural space, with its distinctive language and heritage undoubtedly constitutes a cultural specificity for non-Australian readers - closeness to the source text, which is demanded by theorists of equivalence, does not guarantee a translation that will be well received by the target

It includes one story by an indigenous writer, Archie Weller's "The Fish." The rest of the book is devoted to stories by Australian authors Tom Winton, Peter Carey, David Malouf, Frank Moorhouse, Kenneth Cook, and others.

2 The Slovene version of this "sobering chronicle of the attempted genocide in the $19^{\text {th }}$ century Australia" is entitled Terra nullius: Potovanje po nikogaršnji zemlji. 
audience. Most critics agree that translators have to aim for a balance between comprehensibility and foreignness (Anderman and Rogers 2003). When evaluating a translation, it is thus of particular importance to establish whether it is a faithful transference of the source text and at the same time communicatively acceptable for the contemporary target readers. In light of these questions, I aim to analyse how particular writing styles and cultural signifiers of the Aboriginal originals (such as oral and colloquial expressions and words in Aboriginal English) have been transferred from the source to the target texts, and to examine the different strategies employed to bring Aboriginal writing to a Slovene readership. In particular, this discussion will focus on the domestication and foreignisation strategies in Slovene translations of Sally Morgan's My Place and Doris Pilkington's Follow the Rabbit-Proof Fence (in later publications entitled Rabbit-Proof Fence), thereby demonstrating how successfully these translations narrow the gap between the culture of the source text and that of the target audience.

\section{My Place}

An immediately noticeable difference between the Slovene translation of Sally Morgan's autobiography and the original publication by Fremantle Arts Centre Press in 1987 is its tripartite division. Like Morgan's My Place for Young Readers (1990), an abridged version of the original text, and unlike the source text, the Slovene version consists of three separate books, subtitled Sallyina zgodba (Sally's Story), Zgodba Arturja Corunne (Arthur Corunna's Story), and Mati in hči (Mother and Daughter). ${ }^{3}$ The translation of the title itself, from My Place into $V$ objem korenin, also deserves some attention. Whereas in some other European publications the title is a word-forword translation (in the Czech translation, the title is Sem patrim, in Dutch Mijn Plek) or a slight alteration of the latter (the Italian edition is entitled La mia Australia), Tamara Bosnič took the liberty of translating it with a poetic noun phrase meaning 'to the embrace of the roots.'

Judging by the title, it would be reasonable to assume that the entire text is translated with sophistication and poetic finesse. However, this is hardly the case with Bosnic regularly manipulating the stylistic patterns and register of the source text. Rather than finding a style that would achieve the same effect as the original, Bosnič did not hesitate to occasionally simplify sentences by omitting various words (very often adjectives) or by reformulating long sentences into shorter and easier ones, as if her target audience were young readers. The translator's tendency to simplification is well-noticed in the translation of the following sentence:

"Mum," I complained as I tried to fight my way through the buckets to the toilet, "you won't need all these flowers, and what on earth are these for?" I called as I spied a huge carton of plastic roses. (131)

The Slovene translation renders this as:

"Mama," sem se razburjala, ko sem se poskušala prebiti do stranišča, "saj ne bomo potrebovali

The source text is a single entity, consisting of thirty-two chapters, each of them numbered and bearing a title. The titles, "Arthur Corunna's Story," "Gladys Corunna Story," and "Daisy Corunna's Story," introduce the three narratives incorporated within chapters twenty six, thirty, and thirty-two, respectively.

4 Bosnič did not translate the author's introductory dedication, from which Morgan took the book's title; nor did she translate the contents page that lists all the chapters. Contrariwise, the Slovene version opens with a page-long overview of the author's personal and literary life, whereas the phrase in the title, 'v objem korenin,' closes a brief account on the back cover of the main protagonist's tracing of her family's ethnic background. The final sentence of this account reads: "Odloci se slediti izrocilu svojih prednikov in se vrniti v objem korenin." (She [Sally] decides to follow the tradition of her ancestors and return to the embrace of the roots.) 
vseh teh rož. Kaj pa te počnejo tukaj?” Kriknila sem, ko sem zagledala veliko škatlo rezanih vrtnic. (212)

which might be back-translated into English like this:

"Mum," I complained as I tried to fight my way to the toilet, "we won't need all these flowers." What are these doing here?" When I saw a huge carton of cut roses, I shouted.

We can see that, in addition to providing some incorrect equivalents (rezane vrtnice for plastic roses, kriknila sem for I called) and omitting words, Bosnič split one long sentence into three short ones. Moreover, she was not adequately mindful of the word order - in the Slovene language, the word order is a very flexible grammatical category, often adjusted for emphasis or stylistic reasons - so the meaning of the translated passage is to some extent insufficient. In the next example, we can again perceive relevant differences in comparison with the source text. The paragraph is simplified to the extent that it reads as a kind of resume:

This indulgence took the form of unlimited lollies and fruit, rather than new clothes, toys or books. She'd managed to take us all to the Royal Show the year before, and this year, she told us that, because of her new job, we would really do it in style. (68)

In Bosnič's translation it is rendered in the following way:

Razvajanje pa je šlo predvsem v smeri neomejenega števila lizik in sadja; za novo obleko, igrače ali knjige ga je še vedno primanjkovalo. Leto prej nas je peljala na Kraljevsko predstavo, $\mathrm{z}$ več zasluženega denarja pa je to leto načrtovala ogled na nivoju. (107)

Translated back into English, this paragraph would read:

This indulgence took the form of unlimited lollies and fruit mainly; for new clothes, toys or books it [money] was still insufficient. A year before, she took us to the Royal Show; with bigger earnings, this year she was planning to see the performance in style.

Given the three books' physical appearances, notable for their eye-catching covers, a rather large hardbound format and an appealing typeface, allowing for no more than twenty-nine lines per page, the publisher, too, seems to have been aiming at a young audience. Readers of this essay may also be intrigued by the fact that some Slovene book stores display the book in the youth and children's section. ${ }^{5}$

Bosnič did better in her role as a mediator or negotiator between the two cultures. She operated with an awareness of what was acceptable or alien to the target culture, but her presuppositions regarding Slovene readers' knowledge of the source text culture were not always correct. Only rarely did she find a literal translation insufficient for a certain culturally remote phenomenon or word and supplement it with an additional explanation or description. For example, she thoroughly explained the word Vegemite as a "traditional dark brown Australian food paste made from yeast

Although it is not within the scope of this paper to analyse what Gerard Genette refers to as "peritexts," i.e., those textual elements of translated works that are not part of direct translations of the source texts, but have been shaped independently by the publishers, translators, and editors (like introductions, epilogues, and dust covers with cover illustrations and blurb), it should be noted in passing that, in the case of this Slovene publication in particular, these reflect romantic and exotic imaginings of Aboriginal culture (Haag 2009). Like publications in other European languages, Slovene publications of Aboriginal works provide evidence of how translators, editors, publishers, and advertisers tend to project false generalisations and stereotyped images in order to market the books. 
extract and vegetable, which is usually consumed as a spread for toast [...] or as a substitute for salt," but this is the only footnote in the first book (22). Occasionally, the translator used words with similar connotation in Slovene culture, such as stave for TAB (Australia’s premier betting site), vojni ujetniki for POW (Prisoners of War) transport, Loterija for Raffles, Društvo za zaščito živali for RCPCA (Royal Society for the Prevention of Cruelty to Animals), etc., which contributes to the assimilation of the text into Slovene culture, whereas at other times she retained some expressions that have almost no communicative function for a Slovene readership, or are known only to informed readers (for example Guy Fawkes night, Anzac Day, Frere Jacques, softball, Fahrenheit, and the like), thus reinforcing the foreignising effect. Rather than providing explanations in footnotes, she compelled readers to investigate their meaning elsewhere, which only the most diligent readers will do. Nor was it appropriate to simply omit those culturally marked words that seem to have been too problematic (i.e., Avon ladies), because this, too, functions as a hindrance to the effective comprehension of the narrative and inhibits a real encounter between the two cultures. Similarly, and regardless of the prevailing tendency in her translation to retain geographical and personal names in their original forms, Bosnič either translated a few personal names (e.g., Curly into Koder, which is a literal translation), or chose words that are a kind of adaptation of those used in Slovene culture (Ciril for Cyril). The same logic must also have been at work behind the translator's decision to render the English word $O K$ as okej instead of using one of several Slovene equivalents ( $v$ redu, prav or dobro).

Not only is the cultural repository contained in the original book somewhat problematic in a text addressing a Slovene readership; the source language, with its occasional departures from Standard English, also presents difficulties. David Limon is right to claim that the communicative acceptability of any translated text depends on both how the translator deals with the cultural and conceptual foreignness of the source text, and how he or she deals with the differences between two languages (641). Of prime importance here is for the translator to differentiate incidental differences between the two linguistic systems (e.g., word order) from the writer's conscious departures from conventional stylistic and lexico-grammatical norms, such as repetitions, colloquialisms, unusual order of sentence elements, etc. (ibid.). Given the differences between the linguistic systems of Slovene and English, establishing a similar mixture of formal and informal language as in the original is surely not an easy task. But this cannot be an excuse for almost neglecting this kind of stylistic marker, as is the case with Bosničs translation. With a few exceptions, all of them lexical, Bosnič failed to reconstruct the occasional colloquial speech of the original. In the chapter Drinking Men, where the title itself alludes to the crudeness of diction, the translator tried to preserve the flavour of slang by occasionally using words other than those from the formal vocabulary - words such as mularija and ženšce, pejorative terms meaning kids and woman respectively, the informal expressions fentati and $\check{z}$ reti for the verbs to kill and eat in the original text ( $\check{z}$ reti has a negative connotation, meaning 'to gobble,' most often associated with animals), the pejorative adjective zarukani for stupid, etc. Several other examples show that the translator paid scant regard to Aboriginal English diction because grammatically correct Slovene literary language is used:

"Če ti bodo še kaj težili zaradi starega denarja, jim reci, da nič ne veš o tem. [...] "Babica," sem se nasmehnila, "nikogar iz vlade ne bo, ki bi kaj takega počel.” (153)

"Ničesar ne veš," punca. "Me spet poskušaš prelisičiti, ne? Aah, ne morem ti zaupati. Nisem neumna, veš. Ničesar ne bom rekla. Ničesar, slišišs!” (169)

Translated back into English these passages might read like this:

"If they pester you about the old money, tell them that you don't know anything about 
it." [...] "Grandmother," I laughed, "there won't be anybody from the government to do something like this."

"You don't know anything," girl. "Are you trying to deceive me again? Aah, I can't trust you. I'm not stupid, you know. I won't say anything. Anything, do you hear?"

The original text, however, reads as follows:

"If they pester you about the old money, you just say you don't know nothin'. [...] "Nan," I half laughed, "no one from the government is gunna come round and do that." (96)

"You don't know nothin'," girl. [...] "You're tryin' to trick me again. Aaah, you can't be trusted. I'm not stupid, you know. I'm not saying nothing. Nothing, do you hear." (105)

These examples show that the translator not only failed to reconstruct the deviations from conventional forms with a similar effect as the double negative and sound reductions in the source text, but also used formal vocabulary. For example, instead of translating the verb to trick with the expressive Slovene idiom 'potegniti za nos,' Bosnič chose a very formal equivalent, prelisičiti. When handling swearing, the translator preserved the slang flavour and the expressiveness of idioms. Rather than using English counterparts, she chose phrases and words that are more typical of Slovene, which adds to the domestication of the translation.

The translation of the Aboriginal English words Blackfella and Boong is also quite interesting. Bosnič translated both as crnuh, which is a very offensive Slovene word for a person belonging to a dark-skinned race. Her choice, implying cultural and ethical insensitivity, is a good example that domestication is, in Lawrence Venuti's definition, "an ethnocentric reduction of the foreign text to the target cultural values" and thus not always in the interest of democratic geopolitical relations (Venuti 1995, 20). It also justifies Venuti's claim that "insofar as foreignizing translation seeks to restrain the ethnocentric violence of translation," it is highly desirable today (ibid.). Clearly, Slovene translators have not paid enough attention to the complexity of cross-cultural communication: Andreja Blazič-Klemenc, in her translation of Doris Pilkington's Rabbit-Proof Fence, entitled Zajčja ograja, also used the same ethically problematic and racially prejudiced word crnuh for Blackfella and Boong. ${ }^{6}$

\section{Rabbit-Proof Fence}

How does Zajčja ograja compare with the translation of My Place, when viewed from other perspectives? Beginning with the book's appearance, like other European translations of Australian indigenous literature, Zajčja ograja is visually very attractive, boasting careful design and fine quality paper. The chapter titles are richly adorned with typical Aboriginal ornamentation, similar to those on the delightful pictorial covers. The latter are a product of the European audience's "romantic, misinformed fabulations about Aborigines as a special kind of 'noble savage" and are not a true reflection of Aboriginal realities (Wimmer 2009, 117). ${ }^{7}$

Unlike Tamara Bosnič, Andreja Blažič-Klemenc operated with the precision and know-how of a

In stark contrast to the Slovene versions of My Place and Rabbit-Proof Fence, the German and Dutch editions (provided by Orlanda Frauenverlag and Eva Wolff respectively) did not translate the words Blackfella and Boong with racially prejudiced terminology, but used neutral expressions meaning 'black human'. Maurizio Bartocci, the Italian translator of My Place, left these words untranslated and provided the explanation in footnotes. On the other hand, Marina Rullo, the translator of Rabbit-Proof Fence, rendered these words into Italian as muso nero (meaning 'a very annoying black person'), which is again problematic as it tends to reinforce rather than counteract racism.

As discussed by Oliver Haag among others, the romantic or exotic discourse mostly depicts indigenous people as half-naked, dark-skinned, decorated with body paint and holding artefacts like didgeridoos and boomerangs in their hands (2009). 
skilful translator, attentively following the author's words and thoughts, and showing sensibility for the spirit of both languages. In comparing the translation with the source text, there are only a few discrepancies in the meaning of certain words, but this is not detrimental to the story itself. If one puts aside her inability to deal with colloquialisms and some other minor flaws, the translator managed to adequately reconstruct the original text's model of the world and offered an accurate equivalent of the inner-textual narrative perspective. However, these were not at the expense of the communicative function of the translation. On the one hand, Blažič-Klemenc presupposes information known to the Slovene readership, while on the other hand, she brings Aboriginal culture closer to that readership. Yet her translation reveals some inconsistencies. These are particularly evident in geographical names containing words like sound, river, lake, desert, and route. In most cases, she provided a literal translation of these words, whereas in some others she retained them in English. In replacing the unknown and strange with elements familiar to the target readership, Blažič-Klemenc also made some mistakes. For example, when she translated the expression native settlement in "The Moore River Native Settlement," she omitted the adjective native and merely rendered it as naselje, meaning 'a group of houses and buildings where people live'. To provide a clearer translation, she should have used the Slovene word naselbina, which means 'a group of houses and buildings where indigenous people (or ethnical minority) live'. As evident from this definition, this noun is self-sufficient without the accompanying adjective. Clearly, in this instance, the translator was not sensitive enough to historical detail and failed to establish an important aspect of Australian history.

As mentioned earlier, Andreja Blažič-Klemenc, too, translated the word Blackfella as črnuh, a word that is a product of preconceptions or prejudice. As for other Aboriginal words, they are kept in their original form and explained in the glossary at the end of the book. The Slovene version of the glossary is longer than that in the original (the words added are: coolamon, gidgee, mallee, marri, mulga, neked, wandoo, and the Latin expression Chamaelaucium uncinatum). In addition, the translated text contains some words (mulga, woomera, woodarchy, dawuja, etc.) that are domesticated only in so far as to follow the rules of Slovene declination.

Like Tamara Bosnič, who paid scant regard to the colloquial language in My Place, Andreja BlažičKlemenc failed to produce a counterpart with a flavour of slang similar to Pilkington's colloquial diction. Rather, she mainly used words from formal vocabulary, while producing grammatically correct sentences. For example, "We gotta get away from this bad place" (86) is rendered in Slovene as "Proč moramo s tega zloveščega kraja" (138). This sentence is not only grammatically correct, but is also very formal: the adjective bad is translated with the word zlovešc (sinister, ominous), which is rare in spoken Slovene. The oral characteristics of Aboriginal literature have in this instance not been translated into Slovene. Several other examples give evidence that the translator gave preference to formal words, and gave undue respect to the conventional order of sentence elements, declination, gender, verb forms, and other stylistic markers of standard Slovene. Let us compare the following passage:

"Well, you girls want to be careful, this country different from ours, you know," advised the old man [...]. "They got a Mardu policeman, a proper cheeky fullah. He flog 'em young gel runaway gels like you three," he added [...]. "He follow runaway gels and take 'em back to the settlement. He's a good tracker, that Mardu," the old man told them (91). 
Klemenc-Blažič rendered this as:

Kar previdne bodite, punce, ta dežela je drugačna od naše, veste," jim je svetoval starejši moški [...]. "Mardujskega policista imajo, pravega grobijana. Tepe mlade prebežnice, kot ste ve tri," je pristavil [...]. "Sledi prebežnicam in jih vodi nazaj v naselje. Tisti Mardu je dober zasledovalec," jim je povedal starec (144).

Except for the word punce for girls/gels in the original, Klemenc-Blažič used formal words (grobijan for cheeky fullah, prebežnice for young gel runaway) and did not manage to reconstruct any of the specificities of English colloquialism.

\section{Conclusion}

Generally speaking, this discussion has shed light on what happens to a book when it is translated and circulated in a foreign culture, how it functions when the text is transmitted between a source and a target readership. It also shows that translators have to be alert to the dangers that domestication induces if they are to produce culturally and ethically sensitive translations. In particular, my survey of the two Slovene translations reveals that Zajčja ograja (Rabbit-Proof Fence) is a considerably more successful translation than Vobjem korenin (My Place). Neither Andreja Blažič-Klemenc, the translator of the former, nor Tamara Bosnič, who translated My Place, considered the act of translating as "mere linguistic transference of signifiers," as it is regarded by theorists of equivalence; rather, each viewed the translation act as a "cross-cultural act that involves the problematic discursive travelling from one culture to another," though only Zajcja ograja satisfactorily reproduces the source text and is at the same time communicatively acceptable to the contemporary Slovene reader (Suoqiao 2009, 374). If it were not for the failed reconstruction of the dialect and slang used by the author to reproduce the colloquial diction of the protagonists, and some difficulties with the specificities of Australian history, Zajčja ograja would be a good example to oppose Venuti's claim in The Translation Studies Reader that the communication of the foreign experience through "domestic" means cannot be but "partial and second-order" (Limon 2003 , 642). But even so, the translation is good reading for the target readers and functions as a literary text of its own merit.

Rather than being the work of a skilful translator, Vobjem korenin, on the other hand, is the work of an enthusiast who hoped her translation would enable Slovene readers to be acquainted with the author. There are several reasons to support my premise that this publication does not provide a real encounter between Slovene readers and the author, but the placing of this book in the youth and children's section of some Slovene bookstores alone is indicative enough of the correctness of the critique. As in some other cases of unauthorised editorial intrusions to Aboriginal texts, ${ }^{8}$ discussed by leading Aboriginal literature scholars, including Adam Shoemaker, Tamara Bosnič went too far with her interventions in the text, while the publisher was manipulative regarding the design of the book. If anything, this adaptation of Aboriginal text demonstrates the constant need for new translations. If it is to perform its role as an "act of communication occurring in varying cultural contexts" and at the same time function as an aesthetic masterpiece, the new translation of Morgan's book will have to be more reader-friendly, culturally and ethically sensitive, and technically much more competent (Arens 2005, 136).

8 In Slovene translations of Aboriginal literature, such intrusions can also be found in the 2003 collections of poetry, Vesolje okrog kuščarja and Konec sanjske dobe. 


\section{Bibliography}

Anderman, G., and M. Rogers. 2003. Translation Today: Trends and Perspectives. Clevedon, Buffalo, Toronto, Sydney: Multilingual Matters Limited.

Arens, K. 2005. When Comparative Literature Becomes Cultural Studies. Comparatist 29 (May): 123-47.

Di Luzio, A., S. Guenthner, and F. Orletti. 2001. Culture in Communication: Analyses of Intercultural Situations. Amsterdam/Philadelphia: John Benjamin's Publishing Company.

Genette, G. 1997. Paratexts. Thresholds of Interpretation. Cambridge: Cambridge UP.

Haag, O. 2009. Indigenous Australian Literature in German. Some Considerations on Reception, Publication and Translation. JASAL, Special Issue. See http://www.nla.gov.au/openpublish/index.php/jasal/article/ view/853/1745 (accessed 19 July 2009).

Limon, D. 2003. The Slovene Novel in English: Bridging the Cultural Gap. In Slovenski roman, ed. M. Hladnik and G. Kocijan, 637-43. Ljubljana: Center za slovenščino kot drugi/tuji jezik pri Oddelku za slovenistiko Filozofske fakultete Univerze v Ljubljani.

Mazi-Leskovar, D. 2009. Leatherstocking Tales: $20^{\text {th }}$ Century Slovenian Translations. Acta Neophilologica 42, no. 1-2: 57-68.

Morgan, S. 1987. My Place. Fremantle: Fremantle Arts Centre Press.

- -. 1990. My Place for Young Readers. Fremantle: Fremantle Arts Centre Press.

- -. 1994. Mijn plek. Autobiografie over drie generaties Aboriginals (My Place). Trans. E. Wolff. Amsterdam: In de Knipscheer.

- -. 2000. La mia Australia (My Place). Trans. M. Bartocci. Ancona-Milano: Theoria.

- -. 2002. Sem patř́m (My Place). Trans. V. Piskoř. Praha: Fraktály.

- -. 2007. Vobjem korenin (My Place). Trans. T. Bosnič. Dob pri Domžalah: Miš.

Pilkington, D. 1996. Follow the Rabbit-Proof Fence. New York: Miramax Books.

---. 2008. Zajčja ograja (Rabbit-Proof Fence). Trans. A. Blažič-Klemenc. Nova Gorica: Eno.

Pribac, B. 2003. Konec sanjske dobe: Antoloski prerez sodobne avstralske aboriginske poezije. Ljubljana: Društvo 2000.

Pribac, B., and D. Brooks. 2003. Vesolje okrog kuščarja. Ljubljana: Mladinska knjiga.

Shoemaker, A. 1989. Black Words White Page: Aboriginal Literature, 1929-1988. St. Lucia: Queensland UP. See http://epress.anu.edu.au/bwwp/mobile devices/ch08.html (accessed 14 October 2008).

Suoqiaon, Q. 2009. Confucius as an English Gentleman: Gu Hongming's Translation of Confucian Classics. In Discontinuities and Displacements: Studies in Comparative Literature, ed. E.F. Coutinho, 373-82. Rio de Janeiro: Aeroplano.

Toury, G. 1995. Descriptive Translation Studies and Beyond. Amsterdam/Philadelphia: John Benjamins.

Venuti, L. 1995. The Translator's Invisibility: A History of Translation. London, New York: Routledge.

- - - 2000. The Translation Studies Reader. London, New York: Routledge.

Walker, K. 1977. Widziadta (Stradbroke Dreamtime). Trans. A. Przedpelska- Trzeciakowska. Warszaw: Nasza Księgarnia.

Wimmer, A. 2010. Autonomous Aboriginal Communities in Australia: Besieged by Scandal and Corruption, How Can They Move Forward?" Acta Neophilologica 42, no. 1-2: 111-22. 